\title{
KALAM MODERN: SEBUAH PARADIGMA BARU
}

\author{
Febri Hijroh Mukhlis \\ Dosen Institut Agama Islam Sunan Giri (INSURI) Ponorogo \\ hi_jroh@yahoo.co.id
}

Diterima 03 Mei 2018 | Direview 19 September 2018 | Diterbitkan 01 Oktober 2018

\begin{abstract}
This study highlights the tendency of "Ilm al-Kalam or sometimes called "Islamic scholastic theology" which is one of the less developed Islamic studies. The author proposes that developing this study requires criticism and a new, more contextual approach. One of the most urgent in Kalam's study is to include contemporary contextual themes such as social, bumanity, culture and technology. Therefore, the study orientation of Kalam on the issue of divinity (theocentric) must be transformed into the issue of humanity (anthropocentric). For this reason, Kalam's study must be interdisciplinary with the social sciences and other modern bumanities.
\end{abstract}

Keywords: 'Ilm al-Kalām, Islamic Studies, Theocentric, Anthropocentric

Abstrak:

Studi ini menyoroti kecenderungan "Ilm al-Kaläm atau kadang-kadang disebut "teolog skolastik. Islam" yang merupakan salah satu ilmu Islam yang kurang berkembang. Penulis mengusulkan babwa mengembangkan penelitian ini membutubkan kritik. dan pendekatan baru yang lebih kontekstual. Salah satu yang paling mendesak dalam studi Kalam adalah memasukean tema kontekstual kontemporer seperti sosial, kemanusiaan, budaya, dan teknologi. Oleh karena itu, orientasi studi Kalam pada masalah keilabian (teosentris) harus ditransformasikan menjadi masalah kemanusiaan (antroposentris). Untuk alasan ini, studi Kalam harus interdisipliner dengan ilmu sosial dan bumaniora modern lainnya.

Kata kunci: Ilmu Kalam, Ilmu Islam, Teosentris, Antroposentris.

\section{Pendahuluan}

Salah satu rumpun ilmu-ilmu keislaman (Islamic studies) yang jarang sekali mendapatkan perhatian adalah ilmu kalam (Islamic theology). Padahal ilmu ini termasuk sentral dan pokok dalam ilmu ushuluddin. Kebanyakan pengkaji ilmu-ilmu keislaman lebih banyak bicara perihal sumber pokok, yakni al-Qur'an dan sunnah. Meskipun terkadang juga bicara hukum islam. Sayangnya persoalan teologi yang sebenarnya menjadi bagian penting dari akidah/keyakinan kian luput dari perhatian. Kenyataan ini memicu kemandekan ilmu kalam, terutama terhadap kajian-kajian dalam ilmu modern (social science). Upaya melahirkan kembali ilmu kalan seringkali tidak tuntas. Padahal ilmu kalam memberikan perspektif sejarah teologis tentang teori-teori ketuhanan. Mungkin ilmu kalam menjadi tidak menarik karena ranah kajiannya tidak pernah berkembang atau sengaja dibiarkan. Kajian ilmu kalam masih saja bicara dalam perspektif historis-konfliktual, bisa saja banyak kalangan yang bosan mendengar ulasan kalam yang kaku dan tidak pernah baru. Baru di sini dimaksudkan kalam tidak melahirkan produk keilmuan yang menyangkut persoalan-persoalan kekinian.

Pada era global, manusia kian dipertemukan dengan keragaman pengetahuan, budaya, adat istiadat, dan teknologi. Mengenai semua itu manusia senantiasa berhadapan dengan realitas yang baru pula. Semua ranah dan prinsip kehidupan bicara persoalan yang sama. Dalam perspektif agama, science, budaya, ekonomi dan sebagainya. Tidak luput perspektif teologis juga turut menyertainya. Hanya saja prinsip teologis semacam apa yang turut menyertai kehidupan manusia? Apakah prinsip ketuhanannya berlatar konflik atau toleransi? Bagaimana teologi menjadi bagian dari kehidupan dunia modern? Lantas bagaimana teologi/ilmu kalam mengcounter kenyataan baru globaliasasi yang terus bergerak?

Pertanyaan tersebut selalu menyertai kajian seputar ilmu-ilmu modern. Demikian pula dalam ilmu-ilmu keislaman (Islamic studies) baik praksis maupun teoritis. Lebih jauh permasalahan ini melebar dalam beragam tinjauan. Baik epistemologis maupun ontologis. Perbicangan yang sering muncul, bagaimana ilmu-ilmu keislaman turut menjadi solusi 
perdamaian dunia? Apa kontribusi ilmu-ilmu keislaman dalam memperbincangkan Islam dunia, seputar science dan teknologi? Lebih dari itu tinjauan kritis terhadap ilmu kalam juga sering dikaitkan adanya dikotomi serta penolakan pendekatan ilmu-ilmu modern dalam kajian studi Islam. Hal ini kian menjauhkan ilmu-ilmu keislaman dari proses pengembangannya.

Latar belakang kemandekan ilmu kalam juga bersumber dari peristiwa sejarah. Sejarah klasik banyak menunjukkan kenyataan bahwa kalam selalu menyuguhkan sejarah berdarahdarah. Konflik yang seringkali terekam dalam ilmu kalam menjadikan arah kajian ilmu ini tidak memiliki arti. Manakala kalam menjadi bagian dari ilmu-ilmu keislaman yang wajib diketahui, disisi lain kalam masih saja mewacanakan kajian seputar sejarah konflik dan pertikaian.

Apa yang terekam dalam ilmu kalam sering kali memicu emosi. Sepertinya karakter ilmu kalam seperti ini sarat dengan kepentingan. Lebih bermasalah lagi jika ilmu ini dipandang secara salah, justru melahirkan konflik-konflik baru dalam internal umat Islam. Sudah cukup saya kira sejarah perpecahan umat Islam yang banyak direkam dalam kajian ilmu kalam. Cukup menjadi pembelajaran agar penyulut konflik saling tuduh ini berakhir dan digantikan dengan cara pandang yang cinta-damai.

Memang ilmu kalam berkembang tanpa perubahan. Meskipun telah banyak upaya pengembangan ilmu kalam, namun sepertinya belum mendapatkan banyak perhatian serius. Kajian kritis bahkan liberal dalam ilmu kalam sering kali dilakukan, namun seringkali gagal dan tidak sampai ke tujuan. Buktinya tidak banyak produk ilmu kalam yang lahir dibandingkan tafsir maupun fikih. Ini menandakan minat kajian kalam masih jauh, padahal ini satu-satunya ilmu yang memberikan perspektif menarik tentang kajian teologis.

Kekakuan dan produktifitas yang mandek dalam ilmu kalam ini disebabkan oleh banyak hal, baik berlatar sejarah, kepentingan/politis, nalar/berpikir, pendekatan, dan juga metodologi. Kajian kalam perlu membuka diri member peluang masuknya cara baru dalam memandang seputar dinamika ilmu kalam. Jika tidak demikian ilmu kalam hanya akan menjadi tumpukan sejarah yang mengkisahkan konflik dan perpecahan. Sampai kapan ilmu kalam terus saja bercerita seputar konflik dan perpecahan umat Islam? Alangkah baiknya jika ilmu kalam bicara seputar social science, Islamic science, political science, demokrasi, dan sebagainya? Dan alangkah indahnya jika ilmu kalam memberikan kontribusi sebuah pandangan dalam menciptakan perdamaian dunia?

Konsepsi teologis ilmu kalam dalam buku-buku yang berkembang masih berbicara seputar "Tuhan". Konsekuensi ini justru melahirkan tendensi yang berkepanjangan. Konflik yang ada pasti berdebat seputar persepsi ketuhanan, tentang sifat tuhan, surga neraka, tentang dosa, tentang takdir, dst. Persoalan ini tuntas dikaji oleh para pendahulu/mutakallimin. Menurut Hasan Hanafi kajian ilmu kalam seputar ketuhanan (teosentris) sudah selesai, sudah waktunya bicara dimensi diluar ketuhanan, yakni kemanusiaan (antropsosentris). Wilayah ketuhanan dalam ilmu kalam cenderung menutup diri, entah apa alasannya, meskpun ulasannya seputar ketuhanan, namun itu juga merupakan wacana dan penafsiran. Ini yang tidak disepakati banyak kalangan, ketika kalam bicara perspektif ketuhanan yang berbeda-beda tidak diterima sebagai proses penafsiran, tapi final. Justru ini lagi-lagi yang memicu konflik dalam agama, apalagi beda agama.

Ilmu kalam sekarang tidak hanya diajarkan di PTAI/PTAIN. Namun juga diajarkan di sekolah/madrasah. Rujukan ilmu kalam disemua tingkatan pendidikan tidak pernah berubah, apa yang dibicarakan selalu sama dan tidak pernah berkembang. Ditingkat sekolah ilmu kalam bicara seputar perpecahan umat Islam, dimulai terbunuhnya khalifah Utsman, Ali, kemudian terpecahnya umat Islam menjadi Syiah, khawarij, jabariyah, qadariyah, jabariah, dan seterusnya. 
Di PTAI/PTAIN masih sama juga bicara persoalan demikian. Ilmu kalam sepertinya tidak melahirkan produk baru yang segar bicara persoalan baru yang menyenangkan. Watak ilmu kalam bukan melahirkan perpecahan seperti itu. Tapi sayangnya ilmu kalam seringkali dikisahkan sebagai potret terpecahnya umat Islam.

Saya hawatir karakter ilmu kalam demikian justru memicu lahirnya konflik baru. Atau bahkan ilmu kalam yang memicu konflik hingga hari ini karena karakternya demikian. Fanatisme yang ada dalam kalam seperti itu harus segera ditinggalkan. Harus ada perspektif baru dalam ilmu kalam. Kalam harus dibaca secara kritis. Tidak melulu melahirkan multiperspektif yang kemudian menyulut dan melahirkan ormas Islam yang menuhankan kekerasan atas nama jihad. Kenapa ini perlu dihindari? Karena segala bentuk wacana penafsiran yang konfliktual atau pemicunya harus segera dirubah. Tujuannya untuk melahirkan sikap yang toleran dan demokratis.

Ilmu kalam itu posisinya fundamental. Diantara ilmu-ilmu keislaman yang lain ini ilmu yang banyak bicara seputar Tuhan. Bahkan perspektif ketuhanan juga beragam. Juga perlu dipahami ini hasil ijtihad mufassir kalam. Melahirkan ijtihad baru dalam ilmu kalam tidak lantas berdosa, namun wajib. Fanatisme harus dihindari dengan lahirnya model baru dalam ilmu kalam. Tuntutannya ilmu kalam harus membuka perspektif untuk berbicara persoalan yang lebih luas, tentang kemanusiaan, HAM, gender, toleransi, kebudayaan, pengetahan, dst.

Wajah ilmu kalam hingga sekarang ini masih mewarisi fanatisme kesukuan. Sebut saja "Islam identitaas". Ranah pemahaman kalam yang justru melahirkan konflik indentitas masih berlangsung hingga sekarang. Permasalahan ini menjadikan Islam tertinggal dari peradaban yang lebih maju. Islam terus saja bicara sejarah konfliktual. Kalam model seperti ini menggiring pemahaman yang rigid dan beku. Sebagai satu-satunya ilmu keislaman yang mengusung pemahaman teologis/ketuhanan, kalam harus menjadi pengetahuan yang dinamis dan terus bergerak. ${ }^{1}$

Ilmu kalam atau teologi Islam jika tidak dikembangkan akan mengajarkan perpecahan. Apalagi jika ilmu kalam hanya didekati dengan cara yang tekstual. Pendekatan tekstual terhadap kalam akan menjebak pemahaman kalan pada ranah konflik. Harusnya kalam itu produktif. Konsep teologisnya berkembang. Tekstualitas pemahaman terhadap pemahaman kalam akan menjurus kepada lahirnya fanatismefanatisme kelompok. Orang dengan islam-nya tidak akan bicara berdasarkan nilai kemanusiaan, tapi nilai kepentingan. Padahal jelas sejarah mengingatkan bahwa faktor kepentingan-kedinastian-lah yang menyulut konflik dalam diri agama Islam.

Aspek sejarah kalam sendiri juga seringkali dipahami tekstual. Konsekuensi pemahaman historis-tekstual akan melihat sejarah hanya pada satu sisi saja. Kecenderungan pendekatan seperti ini akan mengarah pada kebekuan ilmu kalam. Dimana kalam sarat dengan kepentingan kelompok. Yang ada justru dalih-dalih teologis untuk melanggengkan kekuasaan tertentu. Atau bahkan dalil-dalil teologis sering kali disalah gunakan untuk menyerang kelompok lain. Jika kalam masih berdimensi historis-tekstual demikian akan muncul cara ber-teologi yang kaku. Ujung-ujungnya saling klaim kebenaran, saling sesat menyesatkan, saling mengakfirkan, dan akan terus saja melahirkan perpecahan. 
Pengulangan pemahaman ini justru terbakukan ketika kalam terkodifikasikan. Pasca kalam terbukukan dalam rumpun keilmuan, ilmu kalam yang kita kenal selalu berkisahkan perpecahan, perbedaan, dan saling klaim. Pandangan tekstual seperti sudah tidak cocok untuk peradaban modern, kalam harus bergerak dan berkembang. Kali ini tugas para "mutakallimin modern" untuk bicara persoalan kalam yang berwajah baru. Tujuan dari pengembangan ilmu kalam adalah mengakhiri adanya kesaling salah pahaman terutama dalam internal agama Islam, saling mengkafirkan, saling mebeda-bedakan, dan sesat menyesatkan.

Fenomena kalam klasik yang terulang bisa kita rasakan hingga sekarang. Banyak kelompok-kelompok Islam yang berbicara atas nama teologis tapi bersikap kasar. Mereka menyebut dirinya beragama tapi tidak toleran dengan sesamanya, bahkan seagamanya. Konflik ini sarat dengan politik-kepentingan. Perpecahan di dunia modern ini mirip dengan perpecahan berabad-abad yang lalu, adanya saling klaim, saling tuduh, saling menyalahkan, saling membunuh, dst. Abad modern lahir kembali (reborn) kelompok-kelompok islamis-jihadis, mereka medakwahkan agamanya dengan kecaman, perang, bom, kerusakan, dan tindakan-tindakan yang tidak manusiawi.

Akhirnya, Islam-pun dikorbankan. Islam menjadi sasaran melekatnya label teroris, radikal, dst. Jika sejarah kalam klasik telah melahirkan perpecahan sekaligus menyulut tindakan-tindakan intoleran, maka sekarang harus diakhiri. Keragaman budaya, agama, adat, dst merupakan fakta baru dunia global. Sampai kapan konflik dalam dan antar agama terus dipertahankan. Korbannya adalah anak-anak tidak berdosa, perusakan fasiltas umum, mengancam perdamaian dunia. Sungguh kenyataan demikian jelas bertentangan dengan visi Islam yang membawa pesan rahmatan lil alamin.

Jika Nabi saja mengajarkan kesantunan dan toleransi bukankah semua umatnya harus berkiblat kepadanya. Jika Islam rahmatan lil alamin bukankah semua rumpun ilmu-ilmu keislaman juga demikian. Termasuk ilmu kalam yang secara khusus banyak bicara persoalan akidah islamiyah, persoalan yang paling sensitif. Cara bertuhannya harus dirubah, perspektif ketuhanannya salah jika Tuhan diimplementasikan dalam bentuk kekerasan dan ancaman. Tuhan itu kuasa dan tidak perlu pembelaan. Seperti kata Gus Dur, Tuhan tidak perlu dibela. ${ }^{2}$ Ia kuasa, Ia besar, Ia tidak akan berubah atas apapun yang dilakukan manusia. Tuhan akan tetap Tuhan meskipun manusia berbuat kesalahan. Tuhan itu merepresentasikan keadilan, demokrasi, toleransi, kerukunan, dst.

Gus Dur sebenarnya mengingatkan konsepsi ketuhanan/teologis/kalam adalah memperjuangkan nilai-nilai kemanusiaan. Manusia yang dibela bukan Tuhan. Manusia hendaknya ber-Tuhan secara santun, toleran dan demokratis. Prinsip teologis seperti inilah salah satu bagian dari pengembangan ilmu kalam. Ilmu kalam harus ditarik keluar untuk berbicara persoalan social-humanities. Teologi Islam yang merupakan aspek keyakinan dalam diri umat muslim harus bergerak dari prinsip yang kaku menjadi aktif. Sehingga teologi mampu membuka diri dengan wacana-wacana baru yang terus berkembang.

Teologi tidak hanya bicara soal Tuhan dan selesai. Tuhan juga berhubungan dengan ciptaan-Nya, manusia, lingkungan, alam dan semesta. Yang membatasi 
pembahsan teologi hanya seputar Tuhan saja itu cara bepikir manusia yang mulai menyempit. Masalah ini dipengaruhi oleh pemahaman sejarah yang tekstual. Sejarah teologis umat Islam hanya berputar-putar bicara soal kontradiksi-kontradiksi dan tidak pernah bicara realitas-realitas yang baru.

Kecenderungan membawa-bawa unsur teologis dalam pertarungan politis sungguh ironis. ${ }^{3}$ Sebaiknya tidak lagi terulang dan menjadi bagian dari umat Islam modern. Ilmu kalam harus berbenah dari pemahaman teosentris ke antroposentris. Dari pemahaman yang politis ke pengetahuan yang dinamis. Dari sini ilmu kalam akan lahir dengan wajah baru yang update terhadap wacana-wacana kekinian. Wajah baru ilmu kalam diharapkan menjadi solusi dari banyaknya kekerasan, intoleransi, dan sikap anti-demokrasi yang mengatasnamakan agama.

Ilmu kalam yang selama ini bicara soal perbedaan-perbedaan seputar kajian teologis harus bicara seputar wacana-wacana kemanusia. Di era global wacanawacana seperti HAM, gender, pluralisme, toleransi, demokrasi, dst merupakan kajian baru bagi ilmu kalam. Kajian teologis tidak bisa untuk menghindar dari kajian ini. Wacana-wacana baru inilah yang justru mampu menghidupkan kembali ilmu kalam. Apalagi perspektif teologis sangat penting pengaruhnya bagi umat Islam, apalagi ketika bicara dosa dan neraka. Untuk itulah mengarahkan kajian teologi bicara persoalan kemanusiaan dan wacana kekinian merupakan sebuah keniscayaan.

Mengapa penting? Wajah baru ilmu kalam harus memberikan pandangan baru tentang tantangan dunia modern. Jika persoalan keimanan dan keyakinan teologis/kalam bersifat lurus teosentris maka corak kalamnya cenderung kaku dan suka saling klaim. Untuk itu wajah baru kalam modern diperlukan untuk menggerakkan ilmu kalam dalam merespon realitas baru yang selalu dijumpai manusia. Sehingga kalam yang sering kali diajarkan dan mengkisahkan perpecahan umat Islam bergeser pada kajian social-science, humanities, cultural studies, religious studies, dst.

\section{Diskurus Kalam dan Problem Epistemologisnya}

Diskusi teologi Islam kian menarik dalam ranah peradaban, baik sosial maupun science. ${ }^{4}$ Tatkala ilmu-ilmu modern berkembang dari situ mestinya teologi bersifat terbuka-aktif menjadi bagian dari pembaharuan. Selubung kebekuan nalar menjadi pemicu kemandekan diskursus teologi Islam. meskipun varian tafsir yang kian beragam sama sekali tidak menggerakkan diskusi teologi untuk berpindah tempat. Selama ini justru asusmi teologis masih bersandar pada wilayah dikotomik-partikular. Masing-masing dimensi yang dikotomis itu saling mendebat satu sama lain, benarbenar sangat disayangkan.

Sebagai ajaran Islam yang paling fundamental, teologi (kalam) mesti menjadi ujung tombak bagi pintu perubahan. Teologi menjadi kunci penting bagi terbukanya saling tegur sapa antar disiplin keilmuan. Keterbatasan pemahaman selama ini bisa dipengaruhi oleh banyak hal, termasuk kultur, tradisi, nalar, metode, dan juga paradigma-politis. Bayang-bayang masa lalu yang keliru dianggap benar, kebenaran berupa pengetahuan kini dianggap salah (bid'ah). Jika terus menerus beranggapan

${ }^{3}$ Febri Hijroh Mukhlis, Kebangkitan Islam Muhammad al-Mustiry: Kritik Atas Tradisi dan Modernitas dalam Dialogia, vol. 14 no. 2 Desember 2016, h. 288. h. $79-80$.

${ }^{4}$ Baca, Amin Abdullah, Falsafah Kalam di Era Postmodernisme (Yogyakarta: Pustaka Pelajar, 2009), 
"yang baru" keliru dan tidak mengikuti sunnah Nabi, maka peradaban Islam tak akan pernah berkembang.

Zaman keemasan Islam kini berada ditangan para muslim generasi baru (milenial). Jika generasi milenial tetap berpangku pada "karya" klasik (taklid) maka akan terjadi pembekuan ajaran. Generasi baru berada pada zaman baru, tentu masalah baru bermunculan, dan itu membutuhkan perangkat baru pula. Sekarang ini karya baru demi peradaban baru mesti dilahirkan kembali, menatap masa lalu sebagai sebuah pembelajaran, dan merajut kembali masa depan dengan harapan pembaharuan.

Halangan bagi pembaharuan seringkali berbenturan dengan tradisi. Model pemikiran klasik tentang teologis sifatnya dibuat seakan-akan "mutlak" dan mengikat. Dengan berdasar pada semua itu maka ijtihad di era baru pun kian dilarang. Nalar kemudian dipaksa untuk tunduk pada mutakallimin klasik, sehingga tak mampu berbuat apa-apa hanya sekedar mengekor saja. Tentu inilah masalah mendasar dalam pembaharuan khazanah teologi Islam.

Teologi basis nilai religious-spiritual memang wilayah yang sangat "privat". Tidak sedikit orang menganggap akidah (teologi) adalah hak individual. Namun jika nalar teologis yang dibangun bersifat eksklusif justru akan melahirkan ekstremismeradikal. Teologi eksklusif bersifat arogan tidak peduli kepada perbedaan, tidak ada toleransi, menganggap dirinya paling benar sendiri. Kebalikan itu ada teologi inklusif yang toleran dan terbuka, ia bersifat privat sekaligus sosial. Inilah problem teologis dalam wilayah kehidupan masyarakat beragama.

Padahal berbeda adalah sunnatullah. Semua manusia berbeda satu sama lain. Berlatar belakang agama, budaya, tradisi, adat, bahasa, dan sebagainya. Kesadaran sosial inilah yang sering kali luput dalam wilayah teologis umat. Sering kali muncul ancaman, kekerasan, karena meninggalkan pandangan yang menjadi inti dari sebuah ajaran. Jika kemanusiaan dijadikan sebagai inti dari ajaran, maka ajaran tidak akan menjadi ajang untuk ekspresi ideologis berupa saling tuduh antar perbedaan.

Begitu sensitifnya tema teologis ini dilakukan pembaharuan, bahkan penulis menyadari betul bahwa wilayah teologis terkadang menjadi ruang yang jarang sekali dikaji dan dibaharukan. Namun tanpa pembaharuan wilayah teologis ini akan terus menerus menuntun para paradigma yang keliru. Bukankah sejarah telah menyebutkan, perdebatan teologis syiah, khawarij, qadariyah, jabariyah, memasuki wilayah teologis. Namun pada waktu itu teologis bersifat konfliktual. Itulah dimulainya sejarah pertikaian politis berunsur teologis.

Teologi adalah ajaran suci berbingkai ketuhanan. Teologi membicarakan yang hakiki dari sebuah keyakinan. Pembelajaran tentang Tuhan tentu tidak terbatas pada wilayah dimana seseorang itu dilahirkan, namun secara lebih luas bicara soal kemanusiaan. Ketuhanan para prinsipnya bukan soal hubungan manusia dengan tuhan, tapi bagaimana hubungan manusia dengan ciptaan Tuhan yang lainnya. Kebanyakan pemahaman teologis masih terbatas pada hubungan manusia dengan Tuhan, tapi melupakan bahwa Tuhan juga menciptakan manusia dan makhluk lainnya, di mana semuanya saling terhubung, saling membutuhkan, dan saling melengkapi satu sama lain.

Maka, terang bahwa problem epistemologis teologi (kalam) berada pada wilayah tradisi berpikir (nalar). Kebanyakan orang terlalu romantis dengan mutallimin klasik, sehingga hirau dengan kemajuan yang ada. Memang pembelajaran dimulai dari 
yang telah ada, namun masa lalu yang tidak kontekstual mestinya dikontekstualisasikan ulang pada zaman sekarang.

Tradisi berpikir kalam harus berubah. Tradisi tersebut bersumber dari kalam yang tengah berkembang hingga sekarang. Jika dahulu praksis kalam menggambarkan fenomena kelompok, kini pengembangan perlu dilakukan. Semua itu bisa dimulai dengan merespon setidaknya tema baru kekinian. Tradisi bernalar yang terjebak oleh tradisi klasik, berupa penutupan pintu ijtihad perlu kembali dibuka. Tradisi teologis yang baru akan memicu pengembangan keilmuan keislaman yang lain.

Kontekstualisasi selama ini seakan ada pada wilayah ilmu tafsir. Namun tidak sepenuhnya demikian, kontekstualisasi berarti pembacaan terhadap konteks. Pendekatan ini diperlukan untuk mengkaji dari aspek historis kalam klasik, hingga melahirkan kalam baru baru konteks baru saat ini. maka sifatnya tetaplah terbuka, jika diperlukan pengembangan lebih lanjut, pintu ijtihat senantiasa terbuka lebar.

Dari sini dapat digaris bawahi bahwa kalam adalah ilmu pengetahuan. Sebagai bagian dari ilmu pengetahuan maka kalam dituntut untuk berkembang. Selama ini buku ajar tentang kalam masih berjalan ditempat, tidak membawa pada perubahan sifat dan karakter pembaca. Apalagi pembacaan sejarah yang juga masih tanpa kritik dan analisa. Keterbatasan itu menjadikan kalam tidak lagi kontributif apalagi produktif.

Sengaja atau tidak selama ini diskursus kalam menjauh dari budaya baca kritis. Pendekatan filosofis jarang sekali ditemukan dalam khazanah kalam modern saat ini. paradigma kalam klasik yang masih bertahan sampai saat ini membelenggu kalam yang mestinya sebagai ilmu pengetahuan hanya sekedar sebagai bukti sejarah. Modal bukti sejarah itulah seharusnya menjadi pintu bagi pendekatan kritis dalam membaca kalam klasik. Para mutakallimin tidak sampai pada pendekatan kritis itu, kini sebuah keniscayaan memandang kalam secara terbuka sebagai pengetahuan.

Dengan cara pandang baru terhadap ilmu kalam, maka di masa depan kalam menjadi bagian dari Islamic science. Penalaran terhadap keilmuan Islam menjadi landasan untuk proyek pengembangan berikutnya. Tentu hal demikian jangan lantas kembali di batasi oleh penalaran tradisional yang beku. Jika kembali terjadi kehentian dalam soal penalaran kritis, maka akan memicu kembali munculnya kekakuan.

Nalar kritis dalam ilmu kalam dapat diperoleh dari pendekatan filosofis maupun hermeneutis. Pedekatan filosofis selama ini meminta seseorang berpikir radikal-kritis. Penalaran filosofis-kritis ini dibutuhkan untuk analisa secara $==$ mendalam terhadap keilmuan kalam (teologi Islam). Kritis dimaksud untuk membuka kran ijtihad agar kembali mengalir, selain itu juga mengkritisi bangunan ilmu kalam yang saat ini tengah berkembang. Tanpa daya kritis semacam ini tidak akan muncul keberanian untuk merekonstruksi atau bahkan dekonstruksi terhadap pemikiran teologis Islam.

Ketakutan penalaran kritis selalu dibayangi oleh tradisi. Perlu disadari bahwa tradisi penalaran masih terkait erat dengan ideologi. Pada masa tertentu ada maksud untuk menjadikan kekuasaan tertentu dikenal secara absolute-paripurna. Pemutusan pada wilayah ideologis demikian justru membatasi ruang kritis bagi pengembangan berikutnya. Tidak perlu tersebut itu pada khazanah klasik maupun kontemporer, jika demikian yang terjadi maka semangat ilmiah dalam keilmuan keIslaman akan berhenti bergerak. 
Sedangkan dimensi hermeneutis dalam kajian kalam bisa digunakan sebagai pembacaan konteks. Juga menjadi sarana kritis untuk membaca kepentingan masa lalu dalam konflik teologis-ideologis dalam peristiwa Syiah dan Khawarij misalnya. Pembacaan secara hermeneutis sangat mungkin dilakukan demi pemahaman yang komprehensif. Memang selama ini hermeneutis dipahami sebagai alat untuk menafsirkan teks. Namun teks sendiri juga tidak terbatas pada budaya tulis, melainkan juga budaya lisan. Teks bisa berupa wacana, tradisi, budaya, termasuk ajaran. Untuk itu pembacaan ini akan berpengaruh dalam memproduksi ulang ilmu kalam dalam merespon wacana baru yang ters menerus berkembang. ${ }^{5}$

Tradisi ilmiah dalam studi ilmu keislaman bukan lagi sesuatu yang baru sebenarnya. Hanya saja sebagian kalangan cenderung menghindari tradisi pembaharuan. Banyak alasan yang mendasari mulai dari takut dosa, hingga doktrin ajaran yang mengikat. Semua itu problematis karena Islam sebagai ilmu tanpa didasari pengembangan tidak akan mampu berkontribusi bagi peradaban. Terkadang ketakutan atas pembaharuan, karena tidak mampunya membedakan mana wilayah islam normatif dan historis. Keduanya seringkali dicampur sehingga yang semestinya wilayah historis dianggap normatif. Bahkan tidak sedikit pula yang anti terhadap pengembangan. Kebanyakan mereka ini mengidolakan masa lalu, cenderung melupakan masa depan. Jika ilmu-ilmu keIslaman dipandang demikian, tidak ada yang berani menarik secara kritis pada wilayah pengembangan, maka ilmu keislaman akan berjalan di tempat

\section{Tantangan Kalam di Era Modern}

Produksi terhadap ilmu kalam masih sangat terbatas. Kebanyakan formulasi ilmu kalam (generasi) masih dalam tataran wacana, atau hanya sekedar berada dalam narasi pemikiran tokoh tertentu. Hal demikian memang patut untuk diapresiasi, namun pengembangannya menuntut sebuah corak baru dalam warna ilmu kalam di masa kini. Hal ini menjadi alasan mendasar bahwa corak baru ilmu kalam harus kembali dilahirkan. Tertulis dalam buku ilmu kalam yang berkembang, kebanyakan masih bercorak klasik, berisi cerita, dan pertentangan antar sekte. Bahkan mayoritas perguruan tinggi masih menggunakan itu sebagai media pembelajaran. Ada hal yang tidak semestinya diulang, termasuk konflik ajaran teologis-ideologisnya, karena semua itu sangat kontra produktif dengan misi keislaman yang senantiasa dinamis.

Hingga saat ini sebagaian umat Islam masih ada rasa anti-terhadap barat. Tentu masalah ini berbuntut panjang apalagi soal pengetahuan modern. Padahal peradaban saat ini tengah berkembang pesat, menutup diri pada satu peradaban tertentu justru membawa pada kerugian. Bukankah pengetahuan itu milik semua orang, ia tidak bisa dibatasi oleh apapun, baik identitas, budaya, kasta politik, bahkan agama sekalipun. Namun kecenderungan anti terhadap pengetahuan modern berdampak pada landasan epistemologis. Penalaran terhadap bentuk perubahan seringkali dilarang hanya karena beralasan bukan bersumber dari ajaran Islam.

Ada beberapa sebab yang menjadikan pembaharuan keilmuan keislaman tidak berjalan. Pertama, ketundukan kepada tafsiran klasik. Masih banyak saat ini kelompok tertentu bahkan sebagian orang yang mengidolakan secara fanatik ijtihad masa lalu. Baik itu dilakukan oleh fuqoha, mufassir, maupun mutakallimin klasik. Padahal 
tafsiran itu bersifat historis, bukan mutlak. Tafsir berarti hasil ijtihad yang terbatas, batasannya pada ruang dan waktu. Produksi tafsir akan disesuaikan dengan zamannya. Apabila tafsiran itu berbeda zaman, tidak relevan, maka menafsirkan ulang adalah sebuah keniscayaan.

Ilmu pengetahuan itu berkembang dinamis. Seperti halnya ilmu keIslaman, lahir dari ijtihad menafsirkan dari al-Qur'an, dibakukan dalam studi keIslaman, itu semua bersifat keilmuan-historis. Keberadaan ilmu keislaman demikian mendapatkan ranah baru ketika bersentuhan dengan kondisi kekinian. Ketundukan pada yang klasik (romantic) akan membawa kepada kebekuan tradisi (nalar). Seakan-akan apa yang sudah dirumuskan oleh ulama klasik sudah final-paripurna. Padahal tidak demikian, ijtihad itu berada dalam batasan zaman, kini ijtihad kembali dilakukan. Dan, pada dasarnya spirit penafsiran saat ini hampir sama dengan para muakallim klasik, yakni untuk merespan tantangan pada zamannya, itulah yang mesti dilakukan saat ini.

Kedua, maraknya ideologisasi Islam (Islamisme). Islamisme kini gejala yang membuat produktifitas ilmu keislaman berhenti. Secara umum saat ini banyak umat Islam menyibukkan diri dengan organisasi keIslaman, dibandingkan dengan ilmu keIslaman. faktanya lebih sering muncul perdebatan yang sifatnya ideologis dibanding keilmuan. Saat ini umat Islam cenderung terkotak-kotak dalam bentuk organisasi, di mana sudah pasti secara ideologis bersifat tertutup. Jika visi keislaman terus menerus ideologis-keorganisasian maka ilmu keislaman akan sangat sulit berkembang.

Ideologisasi Islam tidak menawarkan banyak kemajuan selain konflik antar perbedaan. Akhirnya saat ini terjadi kerancuan paham, mana ajaran Islam yang benar (normative), dan mana ajaran yang sifatnya ideologis. Kenyataan ini benar adanya, produktifitas ajaran Islam yang sifatnya ideologis digunakan untuk menunjukkan perbedaan dengan kelompok lainnya. Inilah sebabnya ilmu-ilmu keislaman tidak berkembang, ada lapisan ideologis yang sulit ditembus untuk dilakukan pembaharuan. Ketika islam sudah bercampur dengan kepentingan ideologis sudah sukar untuk dibuktikan. Kemenangan yang lahir hanya bersifat standar kelompok (ideologis semata). Jika hal demikian terus menerus terjadi, saling berbenturan satu sama lain, demi mengejar eksistensi, maka nilai-nilai keIslaman akan tercerabut dari akarnya, diganti dengan nalar ideologis yang dibawa oleh masing-masing kelompok.

Nalar ideologis sangat membatasi ruang dalam pembaharuan ilmu keislaman. Nalar ini bersifat structural-kolektif. Seperti halnya sebuah gerakan organisasi, di mana selalu terorganisir dengan rapi demi mengukuhkan ideologi tertentu. Anggota satu dengan lainnya saling bekerja sama demi membangun kekuatan organisasi. Umumnya keberadaan ideologi seperti ini sifatnya tertutup, terutama bagi organisasi lainya, bahkan itu dilakukan secara individual. Nalar ideologis menghentikan gerak pengembangan ilmu keIslaman, karena sifatnya terbatas pada kepentingan tertentu. Dalam rangka pengembangan ilmu keIslaman, nalar seperti ini harus dibebaskan dari segala kepentingan (ideologi). Karena ilmu keIslaman itu tidak terbatas pada apapun, baik itu ideologis, maupun organisasi yang berkembang.

Ketiga, stigma berupa pandangan anti-Barat (keilmuan modern). Di era modern saat ini masih ada golongan yang anti-barat, anti peradaban modern. Bahkan hal-hal baru yang berkembang, baik informasi dan teknologi dianggap sebuah kesesatan. Tentu pandangan ini turut menghambat usaha menafsirkan kembali keilmuan keIslaman. pandangan berupa anti terhadap modernitas ini tidak berdasar, 
apalagi saat semua orang hidup dengan peradaban yang terus menerus berkembang. Islam sendiri tidak bisa menghindari peradaban yang berkembang.

Narasi anti-barat tidak memberi perubahan apa-apa, selain hanya menutup kran ijtihad pengetahuan umat Islam. bukankah ada riwayat hadits yang meminta umat Islam untuk belajar kepada peradaban luar. Itu perintah keilmuan, bahwa narasi ilmuilmu keislaman itu berkembang, tidak ada batasan antara timur dan barat. Ilmu pengetahuan itu milik semua orang, tidak bisa dibatas-batasi dengan cara apapun. Peradaban Islam pernah merasakan kejayaan dibidang ilmu pengetahuan, bahkan satu orang mampu menguasai berbagai disiplin ilmu, selain menguasai teologi (tauhid), juga menguasai ilmu modern, seperti astronomi, kedokteran, matematika, dan science. Jargon anti-Barat (modernitas) benar-benar tidak berdasar. Kebanyakan mereka yang melontarkan penolakan, namun sehari-hari menikmati akses teknologi, menggunakan alat-alat yang senyatanya dibuat oleh mereka (barat).

Lebih jauh masalah ini berimplikasi terhadap menjauhnya ilmu keislaman dari pendekatan-pendekatan kontemporer. Sejauh ini masih banyak kelompok yang menolak menggunakan ilmu-ilmu modern menjadi bagian dari pengembangan ilmuilmu keIslaman. hal ini mempersempit ruang bagi para pembaharu ilmu keislaman karena selalu dibenturkan dengan wacana demikian. Maka ilmu-ilmu keislaman, seperti kalam, fikih, tasawuf, tafsir, senantiasa berjalan di tempat. Baru-baru ini ilmu keislaman sudah mulai dilakukan pembaharuan, meskipun menemui berbagai hambatan, namun segala usaha demikian harus dilakukan.

\section{Sebuah Paradigma Baru}

Kalam sejak dini harus dipahami sebagai ilmu pengetahuan. Pada bagian tertentu ilmu kalam memang bicara tentang ketauhidan, namun kenyataan yang berkembang ilmu kalam klasik masih berparadigma normatif-historis bukan normative-kritis. Sejauh ini kalam sama sekali tidak berdimensi filosofis. Ia masih masih berdimensi tunggal, bahkan seakan-akan berkembang tanpa kritik. Jika terusmenerus kalam tidak dipahami sebagai pengetahuan yang berkembang, maka keberadaaanya tidak akan menjadi salah satu kajian yang menarik lagi. ${ }^{6}$

Tugas paling mendasar saat ini adalah melakukan sebuah perombakan perubahan. Ilmu kalam masih sering dijumpai memberikan pemahaman klasik tentang pergumulan antar kelompok. Suguhan kajiannya masih meninggalkan narasi kedudukan atas kuasa ideologis. Kalam harus keluar dari selubung identitas menuju narasi besar sebagai bagian dari keilmuan. Di perguruan tingga saja ilmu kalam masih tergolong belum berkembang, kalam di perguruan tinggi masih belum ada kombinasi metodologis, sehingga kalam terpisah dari perkembangan ilmu modern.

Berbeda dengan rumpun keilmuan lain, studi Qur'an sampai saat ini sudah terjadi banyak perkembangan. Dari berbagai sisi dimensi kajian tafsir sudah sampai pada kajian living Qur'an bahkan juga menggunakan tradisi kirtis seperti kajian Hermeneutika dalam studi tafsirnya. Begitu pula dalam kajian hadits, terdapat perubahan signifikan, kajiannya berkembang dengan adanya perkembangan pemikiran kritis dalam sebuah bacaan hadits klasik. Juga pada tradisi fikih, sejauh ini tradisi fikih yang dianggap sebagian pemikir cenderung melahirkan tradisi 'taklid', namun juga telah berbenah, kajian fikih juga telah merespon narasi baru sehingga

${ }^{6}$ Febri Hijroh Mukhlis, Model Penelitian Kalam: Teologi Islam Ahmad Hanafi, dalam Dialogia, vol. 13 no. 2 Desember 2015, h. 191. 
lahir studi fikih yang merespon secara khusus tentang isu politik, perempuan, budaya, hubungan antar agama, dan seterusnya.

Kedudukan ilmu kalam ini penting dalam sebuah kajian keislaman. kalam dipahami sebagai ilmu yang mengajarkan tentang dimensi-dimensi ketuhanan. Jangan sampai narasi kalam mengarahkan orang untuk berkonflik kepada yang berbeda. Sebagai bagian dari rumpun keilmuan kalam harus merespon tema-tema baru yang saat-saat ini berkembang. Apalagi tema ketuhanan yang secara khusus dibicarakan dalam ilmu kalam, tentu akan sangat kontributif jika kalam menjadi ujung tombak dalam membentuk sebuah hubungan yang harmonis dilandasi dengan pemahaman ketuhanan yang benar.

Fakta hari ini menunjukkan dalil-dalil ketuhanan dijadikan sebagai senjata untuk menjatuhkan orang lain atau kelompok lain dengan tuduhan kafir dan sesat. Untuk menuntaskan semua itu, kalam memiliki peran penting, kedudukannya sebagai sebuah keilmuan pasti menjadi solusi ketika menghadirkan perspektif ketuhanan yang menyejukkan dan mendamaikan. Maka, saat ini sangat penting untuk memproduksi kembali ilmu kalam dengan wajah baru, dengan paradigma baru yang lebih kekinian untuk merespon zaman baru yang berkembang.

Salah satu tawaran menarik yakni menjadikan kalam tidak anti terhadap kritik. Kalam harus terbuka dalam posisinya sebagai ilmu pengetahuan. Dengan begitu kalam dapat didekati dengan berbagai disiplin keilmuan. Kalam dapat dikiritik dalam hal sejarah dan perkembangannya, kalam juga dapat dikombinasikan dengan pemikiran-pemikiran filsafat. Filsafat bisa jadi alternatif yang paling mungkin, sehingga kalam menjadi ilmu rasional yang kontekstual dalam setiap zamannya. Jangan lagi mencari kesalahan-kesalahan dengan memperdebatkan akal dan wahyu, sebagaimana perdebatan al-Ghazali dan Ibn Rusyd, memang perdebatan keduanya pernah menjadikan pemikiran kritis pecah dalam dua kubu besar, satunya anti filsafat, dan satunya lagi pembela filsafat rasional. Saat ini perdebatan itu melebur dalam zaman baru, bernama modernitas, saat ini dunia membutuhkan sebuah kontribusi dari berbagai dimensi pengetahuan, termasuk diantaranya ilmu-ilmu keIslaman, secara khusus ilmu kalam tentunya.

Di berbagai diskusi akademik maupun majlis ilmiah saat ini harus menjadikan pengetahuan sebagai anak emas. Jangan jadikan dalil pengetahuan menjadi narasi identitas (politik), sudahi saling bertikai dan membenci. Kini saatnya bicara pengetahuan secara menyeluruh. ${ }^{7}$ Ilmu kalam sebagai ilmu ketuhanan wajib memberikan perspektif ketuhanan yang baru. Yakni, dimensi ketuhanan yang mampu merangkul dan mengedepankan keilmuan. Hampir saat ini ketuhanan tidak lagi menjadi sebuah nilai yang tinggi, namun dirusak oleh narasi yang keliru sehingga makna ketuhanan telah bergesar dari makna suci menjadi makna kekerasan dan kekejian. Buktinya, banyak kelompok atas nama agama dan ketuhanan melakukan perusakan, kebencian, bom, pembakaran, pembantaian, dan diskriminasi terhadap kemanusiaan. Keberadaan ilmu kalam dengan paradigma baru dapat diharapkan membawa angin perubahan, dengan membawa nilai-nilai kemanusiaan dalam kajian kalam, maka kalam akan tampak perannya dalam problem kehidupan manusiaan saatsaat ini.

${ }^{7}$ Muhammad al_mustiry, Jadal al-Ta'sil wa al-Mu'asirah fi al-Fikr Islam (Tunisia: Kareem Syarif, 2014), h. 232. 
Sebagai ilmu, kalam harus merespon tema-tema baru (new experience), seperti kemanusiaan, kebudayaan, kebhinekaan, sosial-kemasyarakatan, teknologi, dan ilmu pengetahuan modern. Sejauh ini kalam masih bersifat mondisiplin, berdiri sendiri. Kedepan kalam harus bersifat integratif dan terkoneksi ${ }^{8}$ secara kritis-filosofis dengan berbagai keilmuan berkembang. Dengan integrasi-interkoneksi keilmuan kalam dapat menjadi ilmu yang multidisiplin, terbuka untuk dianalisa dan dikritik, tentu dengan ilmu kalam akan terus menerus dilakukan penelitian sehingga ia berkembang untuk merespon kajian-kajian baru. Selama ini yang menjadikan kalam berhenti berkembang adalah tidak adanya kajian kritis dan pemikiran terbuka. Kali ini kalam harus benarbenar dalam posisinya sebagai pengetahuan yang diharapkan kontribusinya untuk peradaban. Dari berbagai kajian yang multisiplin diharapkan lahir kalam yang berdimensi kekinian, seperti kalam sosial, kalam kebhinekaan, kalam kemanusiaan, kalam kebudayaan, dan seterusnya.

\section{Simpulan}

Kalam merupakan kajian dari berbagai rumpun ilmu-ilmu keIslaman. Kalam sebagai ilmu harus dibebaskan dari sejarah konflik yang mencekam peradaban. Dahulu cerita kalam masih mengabadikan sejarah konfliktual. Saat ini kalam harus jauh dikembangkan untuk merespon masalah-masalah baru di zaman modern. Polemik identitas antar golongan dalam catatan sejarah kalam jangan menjadi warisan turun temurun. Kajian kalam sebagai basis ilmu katauhidan harus menjadi sarana perbaikan dalam peradaban duniawi saat-saat ini. kalam haruslah kajian ketuhanan yang membebaskan. Untuk itu, kalam harus berdialog secara terbuka dan kritis tehadap ilmu-ilmu modern. Hubungan kalam dengan kajian-kajian baru sifatnya haruslah inetgratif-interkonektif. Selama ini kalam sifatnya hanya mondisiplin, dan kini kalam harus bergerak pada kajian yang interdisipliner dengan merespon berbagai perkembangan baru

\section{Daftar Pustaka}

Abdullah, Amin. Falsafah Kalam di Era Postmodernisme. Yogyakarta: Pustaka Pelajar, 2009.

Islamic Studies di Perguruan Tinggi: Pendekatan Inetgratif-Interkonektif. Yogyakarta: Pustaka Pelajar, 2012.

al-Mustiry, Muhammad. Jadal al-Ta'sil wa al-Mu'asirah fi al-Fikr Islam. Tunisia: Kareem Syarif, 2014.

Esha, Muhammad In’am. Falsafah Kalam Sosial. Malang: UIN Maliki Press, 2010.

. Retbinking Kalam. Yogyakarta: Elsaq, 2006.

Mukhlis, Febri Hijroh. Kebangkitan Islam Muhammad al-Mustiry: Kritik Atas Tradisi dan Modernitas dalam Dialogia, vol. 14 no. 2 Desember 2016.

. Model Penelitian Kalam: Teologi Islam Ahmad Hanafi, dalam Dialogia, vol. 13 no. 2 Desember 2015.

Wahid, Abdurrahman. Tuban Tidak Perlu Dibela. Yogyakarta: LKiS, 1999.

${ }^{8}$ Amin Abdullah, Islamic Studies di Perguruan Tinggi: Pendekatan Inetgratif-Interkonektif (Yogyakarta: Pustaka Pelajar, 2012), h. 106. 